\title{
Effect of Work-Life Balance and Welfare Level on Millennial Employee Performance Through Work Engagement
}

\author{
Agis Sa'adah Puspitasari, Muhammad Darwin \\ ${ }^{1}$ ABFI Institute Perbanas, Jakarta, Indonesia \\ ${ }^{2}$ Universitas Nasional, Jakarta, Indonesia \\ Email: agispuspitasari@gmail.com
}

\begin{abstract}
Industrial Revolution 4.0 is a phenomenon that collaborates with cyber technology and automation technology. this research aims to conduct scientific research on the role of worklife balance and the level of welfare of millennial employees through work engagement as a variable intervening. The participation of respondents to this study is the general of millennials who has worked in the Jakarta area, aged 21-36 years. Researchers used the purposive sampling method. This study uses a work-life balance measurement tool with a balance dimension in time management, engagement balance, balance in expectation fulfillment, and satisfaction balance. Besides, at the level of well-being with meaningful worklife factors, good social relationships, work attachment, self-actualization, comfortable circumstances, self-acceptance. While employee performance is measured through the work environment, ability to do work, and motivation. Work Engagement is measured by vigor, dedication, and absorption indicators. The analysis technique used is Structural Equation Modeling based on VB-SEM using SmartPLS software. The results showed that five hypotheses of direct influence were accepted and one rejected. While the two hypotheses of indirect influence are each rejected and accepted. Work Engagement variables as intervening variables are only capable of mediating Work-Life Balance against Employee Performance.
\end{abstract}

Keywords: Millennials, Work-Life Balance, Welfare Level, Employee Performance, Work Engagement.

\section{A. INTRODUCTION}

Industrial Revolution 4.0 is a phenomenon that collaborates with cyber technology and automation technology (Pratiknyo, 2020). Another normality that has begun to take shape is the shift in the mechanisms of public services, economic activity, and industrial process businesses, all of which adopt digital technology (Mckinsey \& Company 2020). Exacerbated by the covid 2019 outbreak spreading throughout the world called pandemic conditions. The current revolution will experience a very rapid shift and the development of disruption will adjust the needs and behaviors of consumers who have to adjust to the pandemic situation (Darwin, 2020).

The rapid growth of the business today requires the company to always excel and compete. In addition to the Industrial Revolution 4.0, the current era is also in the era of VUCA that can affect all aspects, especially economic aspects. The acronym vuca was first used in 1987, warren Bennis and Burt nanus leadership theory to describe the rapid change (Volatility), uncertainty, dynamic environmental 
factors and interdependence (Complexity), unusual circumstances, and one state of interconnectedness (Ambiguity), (Sefudin \& Darwin, 2020). So to be able to be a superior and competitive company, the company needs various ways that are arranged in the program to be able to improve employee performance (Nurwahyuni, 2019). Industry 4.0 which is loaded with technology is a challenge for human resources due to the process of social transformation (Schaar et al., 2019).

Nowadays, the world of work is increasingly diverse with human resources coming from different generations, one of which is the Millenial generation or generation $Y$, which is familiarly called generation me or echo boomers. Generation Y classification is formed for those born in 1980 - 1990, or in early 2000 onwards (setkab.go.id). Millennials are efficient, optimistic, and not much different from other age groups. According to (Wen et al., 2018), millennial employees are considered highly educated, ambitious, and career-oriented. With these characteristics, it is expected that the millennial workforce in the industrial era 4.0 can be more competitive and productive than previous generations to face global competition.

In Research Institute 2019 survey results, looking for better self-development opportunities is the first reason millennials leave the company (26.5\%), for both senior and junior millennials. Millennials live in companies because of creative freedom, flexible working hours, and support teams. Meanwhile, in 2017, 38\% of millennial employees plan to leave their jobs. However, in 2018 as many as $43 \%$ of millennial employees plan to leave their jobs (Deloitte Survey, 2019).

Work engagement is invaluable to workers and organizations because it influences the way employees to work and complete their tasks. So many organizations focus on hiring and retaining proactive employees who are ready to contribute, self-motivated, and forward-thinking in other words the employees involved (Yongxing et al., 2017). Employee work engagement ensures the level of commitment of employees with their organization and leads to better performance and when employees engage in their work and participate in decision making then they feel they have their organization and always do the best for their organization (Rahman et al., 2017). While high levels of work engagement can adversely affect mental health in the short term, its detrimental effects can disappear and even improve mental health in the long run (Tenney, 2016).

According to (Vijayakusumasari \& Vrinda, 2016) various studies revealed that psychological well-being and work engagement contribute to better performance. If employees assume that the organization cares about their well-being and supports them, employees will retaliate and show more involvement in their work and be able to improve their performance (Thibaut \& Kelley, 1959). The percentage of employee performance in Indonesia is still relatively low or in the category of middle-income countries based on the Work Economic Forum (WEF) with a score of 62.19 where the level of Employee Performance in Indonesia in 2019 is ranked 67th out of 130 countries in the world (edukasi.kompas.com, 2019). Research (Gallup, 2016) shows that only $29 \%$ of millennial employees are emotionally and behaviorally engaged with work and company. This is certainly a big loss for the Company, as they only 
appear in business hours but do not provide the best for the development of the Company.

Performance is associated with employee and organizational level results. Performance becomes an attractive variable for scholars and practitioners because of its impact on results affecting the bottom line of the organization (Pandey, 2018). The balance between personal life and work is an important need of every employee that can affect the mood, focus of mind, and actions in carrying out their responsibility both parties, therefore the higher employee satisfaction to work-life balance the higher the quality of employee performance. the study stated (Nafiudin, 2015) that a person will also choose another job or stop to work balancing work and personal life. Ideally, when the company wants to carry out a work-life balance, the company will provide some support to workers. Based on the description, this study aims to conduct scientific research on the role of work-life balance and the level of welfare of millennial employees through work engagement as a variable intervening.

\section{B. LITERATURE REVIEW}

\section{Millennials}

In nindyawati research (2017) that companies that have employees consisting of gen $X$ and gen $Y$ should begin to review related to things that can keep employees retained in the company. This is because it relates to the sustainability of the company itself. The ideal job for millennials is a job that suits their personality, when millennials enjoy their work, it will provide a sense of satisfaction in the work environment and outside the job (Gichuhi \& Mbithuka, 2018). Millennials are divided into two categories: junior millennials, those born from 1992 - 1999 (ages 2128), and senior millennials born between 1984-1991 (age 29-36).

\section{Work-Life Balance}

Work-life balance is a situation where workers feel that they can balance their work and the nonworking commitments they mostly do (Singh and Koradia, 2017). There are several indicators used to measure work-life balance including balance in time management, engagement balance, balance in meeting expectations, and satisfaction balance, Rahmawati (2016). From an employee's point of view, work-life balance can be interpreted as a challenge to be able to balance the responsibility to complete the work and responsibility to perform its role in the family, while in the point of view of the organization work-life balance becomes a challenge to create a supportive work environment so that employees can focus on their achievements in the workplace (Oktaviani, 2015).

\section{Welfare Level}

Workplace well-being plays an important role in creating a thriving employee. Focusing on workplace well-being has provided valuable opportunities to benefit employees by helping employees feel happy, competent, and satisfied in their roles (Utari et al. 2019). Well-being in the workplace is very important for 
individuals because happy individuals in the workplace have positive feelings that make individuals satisfied, productive, and low turnover thus creating quality human resources (Ningsih, 2013). Maximizing and enhancing the role of a qualified workforce has always been one of the most challenging tasks for human resource practitioners. The rise of Millennials makes it difficult for human resource practitioners to manage their workforce. Most organizations today face similar difficulties in engaging the millennial workforce. (Jha, Sareen, \& Potnuru, 2019). Welfare level according to (Nangoy, et.al, 2019) has indicators namely, Meaningful work-life, Good social relationship with work attachment, Self-actualization, Comfortable, and Self-acceptance.

\section{Work Engagement}

Work engagement is invaluable to workers and organizations because it influences the way employees to work and complete their tasks. So many organizations focus on hiring and retaining proactive employees who are ready to contribute, self-motivated, and forward-thinking in other words the employees involved (Yongxing, Hongfei, Baoguo, \& Lei, 2017). In the study (Basikin, 2007) to measure work engagement researchers divided it into three factors, among others vigor, dedication, absorption. Work engagement reflects the personality that employees bring into their work, so employees can be energetic for their work or lead to employee performance.

\section{Employee Performance}

Performance is a success that has been achieved by an employee based on the activities carried out by employees in carrying out their work. Employee performance is the achievement of employees in completing their work within a predetermined period (Paramitadewi, 2017). According to (Johari, 2016) the indicators used as measurements of employee performance are the work environment, the ability to do work, and the presence of motivation. Performance is associated with employee and organizational level results. Performance becomes an attractive variable for scholars and practitioners because of its impact on results affecting the bottom line of the organization, Pandey (2018).

\section{METHOD}

The research method used is a quantitative method on structural equation modeling inferential analysis. There are two types of data in statistics, namely parametric and non-parametric data (Nurwulandari \& Darwin, 2020). By the type of data in this study using parametric inferential data analysis. According to (Haryono, 2016) in (Darwin \& Umam, 2020), there are two types of use of SEM analysis namely, Covarian-based (CB-SEM) and variant (VB-SEM). But in this study using SEM-based variants (VB-SEM). Adapaun software used is SmartPLS. Sampling techniques use non-probability sampling on purposive sampling type. The goal is to qualify and by the right source of information, namely the generate millennials who work in the 
DKI Jakarta area. This study aims to determine the effect of work-life balance and employee welfare level on millennials on their performance in the workplace through work engagement.

\section{RESULTS AND DISCUSSION}

\section{Test the Validity and Reliability of The Construct}

The first time in analyzing the model of measurement equations is to test the validity and reliability of the construct. The expected loading factor criteria limit is $\geq$ 0.4 or $\geq 0.7$, then declared fit (Haryono, 2016). But in this study, researchers used $a \geq$ limit of 0.7 . The algorithm output results in this study that can be shown in table 1 below resulted in the value of outers loading above the expected criteria $(\geq 0.7)$. Then it can be concluded all indicators are fit.

Table 1. Outer Loadings

\begin{tabular}{|c|c|c|c|c|}
\hline & KIN & TKS & WEG & WLB \\
\hline KIN1 & 0,897 & & & \\
\hline KIN2 & 0,852 & & & \\
\hline KIN3 & 0,889 & & & \\
\hline TKS1 & & 0,905 & & \\
\hline TKS2 & & 0,876 & & \\
\hline TKS3 & & 0,914 & & \\
\hline TKS4 & & 0,835 & & \\
\hline WEG1 & & & 0,893 & \\
\hline WEG2 & & & 0,904 & \\
\hline WLB2 & & & & 0,725 \\
\hline WLB3 & & & & 0,798 \\
\hline WLB4 & & & & 0,882 \\
\hline
\end{tabular}

Source: SmartPLS 3, 2021

Furthermore, the criteria of validity and reliability of the construct also show valid and reliable results. As shown in table 2 results below, all variables are above the values of 0.7 in both Cronbach's Alpha and Composite Reliability. Then it can be evaluated with reliable results. While the AVE value is above the limit value of 0.5 , it means that all variables with evaluation are valid.

Table 2. Construct Reliability and Validity

\begin{tabular}{|c|c|c|c|c|}
\hline & $\begin{array}{l}\text { Cronbach's } \\
\text { Alpha }\end{array}$ & rho_A & $\begin{array}{l}\text { Composite } \\
\text { Reliability }\end{array}$ & $\begin{array}{c}\text { Average } \\
\text { Variance } \\
\text { Extracted } \\
\text { (AVE) }\end{array}$ \\
\hline KIN & 0,854 & 0,862 & 0,911 & 0,774 \\
\hline TKS & 0,905 & 0,911 & 0,934 & 0,780 \\
\hline WEG & 0,762 & 0,763 & 0,893 & 0,807 \\
\hline WLB & 0,724 & 0,746 & 0,845 & 0,646 \\
\hline
\end{tabular}




\section{Discriminant Validity Test}

The discriminant validity test is used to test the validity of its construct indicators. It is declared valid if the root value of AVE $>$ is of a correlation value between constructs. In the result of table 3 Cross Loadings below resulted in the ave root value on the diagonal row turned out to be a greater value than the correlation between constructs, so it can be stated by evaluation in this analysis meets the validity of the discriminant.

Table 3. Cross Loadings

\begin{tabular}{l|r|rrr}
\multicolumn{1}{c}{ KIN } & \multicolumn{1}{c}{ TKS } & \multicolumn{1}{l}{ WEG } & \multicolumn{1}{l}{ WLB } \\
\cline { 2 - 3 } KIN1 & 0,897 & 0,678 & 0,492 & 0,620 \\
KIN2 & 0,852 & 0,607 & 0,528 & 0,579 \\
KIN3 & 0,889 & 0,785 & 0,496 & 0,709 \\
TKS1 & 0,721 & 0,905 & 0,326 & 0,699 \\
TKS2 & 0,684 & 0,876 & 0,239 & 0,554 \\
TKS3 & 0,737 & 0,914 & 0,434 & 0,665 \\
TKS4 & 0,641 & 0,835 & 0,321 & 0,543 \\
WEG1 & 0,508 & 0,269 & 0,893 & 0,472 \\
WEG2 & 0,521 & 0,407 & 0,904 & 0,511 \\
\hline WLB2 & 0,425 & 0,327 & 0,593 & 0,725 \\
WLB3 & 0,597 & 0,592 & 0,233 & 0,798 \\
WLB4 & 0,711 & 0,741 & 0,470 & 0,882 \\
\hline
\end{tabular}

\section{Structural Model Test}

To test the structural model it takes the value of $\mathrm{R}$ Square. The structural model can be said to be strong if it has a value of $\geq 0.67$, a moderate model at a value of $\geq 0.3$, a weak model indicated at a value of $\geq 0.19$.

\section{Table 4. R Square}

\begin{tabular}{l|rr|} 
& \multicolumn{1}{c}{$\begin{array}{c}\text { R } \\
\text { Square }\end{array}$} & $\begin{array}{r}\text { R Square } \\
\text { Adjusted }\end{array}$ \\
\hline KIN & 0,728 & 0,720 \\
WEG & 0,300 & 0,287
\end{tabular}

Source: SmartPLS 3, 2021

The results of table 4 above illustrates that $\mathrm{R}$ Square in KIN variables is worth $0.728>0.67$, meaning the influence of exogenous variables on endogenous variables KIN produces a strong model of $72.8 \%$ the rest influenced by variables outside of this study. While WEG intervening variables produce values of $0.3<0.67$ and $\geq 0.3$, meaning WEG intervening variables produce a moderate model. This means that the influence of exogenous variables on WEG intervening variables results in a moderate model of $30 \%$ of the rest influenced by variables outside of this study.

Furthermore, testing the structural model can also be done by analyzing the test of the constructed model that has been built whether it produces a good fit, marginal fit, or bad fit. According to (Ghozali, 2021), the model is said to be fit in sem analysis using SmartPLS required SRMR value should be below 0.08 , NFI value 
should be above 0.90 and rms_Theta should be close to zero value (0). In table 5 below shows that the analysis results have met the fit criteria. An SRMR value of 0.098 close to a value of 0.08 results in a marginal fit evaluation, and an NFI value of 0.745 close to a value of 0.090 results in a marginal fit evaluation, and a rms_Theta value of 0.263 that is close to zero results in a good fit evaluation.

Table 5. Fit Summary

\begin{tabular}{l|rr|} 
& $\begin{array}{r}\text { Saturated } \\
\text { Model }\end{array}$ & $\begin{array}{r}\text { Estimated } \\
\text { Model }\end{array}$ \\
\hline SRMR & 0,098 & 0,098 \\
\hline d_ULS & 0,745 & 0,745 \\
\hline d_G & 0,381 & 0,381 \\
\hline Chi- & 257,637 & 257,637 \\
Square & & 0,745 \\
NFI & 0,745 & \\
rms Theta & 0,263 & \\
\hline
\end{tabular}

Source: SmartPLS 3, 2021

\section{Interpretation}

This study has hypothesized as many as seven hypotheses consisting of five direct influences and two indirect influences. To know the hypothesis is accepted or not, the expected statistical T value limit is $\geq 1.96$ and the expected P-value of $\leq 0.05$. This study obtained the results of the output of the coefficient path produced four hypotheses of direct influence and one significant indirect influence. It is above the cut of value ( $\mathrm{T}$ statistics $\geq 1.96, \mathrm{P}$-value $\leq 0.05$ ), and each 1 hypothesis of direct and indirect influence is insignificant because the value is below the expected cut-off value.

Table 6. Direct Effects

$\begin{array}{lccrrrr} & \begin{array}{c}\text { Original } \\ \text { Sample } \\ \text { (O) }\end{array} & \begin{array}{c}\text { Sample } \\ \text { Mean } \\ \text { (M) }\end{array} & \begin{array}{c}\text { Standard } \\ \text { Deviation } \\ \text { (STDEV) }\end{array} & \begin{array}{c}\text { T Statistics } \\ (\text { IO/STDEVI) }\end{array} & \begin{array}{c}\text { P } \\ \text { Values }\end{array} \\ \text { TKS -> KIN } & 0,553 & 0,551 & 0,104 & 5,319 & 0,000 \\ \text { TKS -> WEG } & -0,011 & -0,005 & 0,103 & 0,104 & 0,458 \\ \text { WEG -> KIN } & 0,254 & 0,253 & 0,065 & 3,930 & 0,000 \\ \text { WLB -> KIN } & 0,200 & 0,204 & 0,105 & 1,898 & 0,029 \\ \text { WLB - }>\text { WEG } & 0,555 & 0,552 & 0,086 & 6,472 & 0,000\end{array}$

Table 6 above shows that the direct relationship between the Welfare Level variable to Work Engagement is invalid and results in an evaluation of the rejected hypothesis. Because the T Satat value is $0.104<1.96$ and the P-Value is $0.458>0.05$. Whereas in direct relation other variables produce valid values and the resulting evaluation of the hypothesis built is accepted. Because all T values are stat $>1.96$ and P-Value $<0.05$.

That is, the Welfare Level Variables in this study had a direct influence on weak Work Engagement. By implication, the respondent's level of perception on the 
variable gauge indicator also results in a low value, especially in the statement item that measures the TKS5 indicator stating that millennial employees' tolerance to their work activities process. The results of the analysis of outer loadings on the TKS5 indicator are below the value of 0.7 which is then dropped from the model path. The level of Well-being that millennial employees felt in this study was not comparable to what they expected. So there is a gap (gap) to Work Engagement, especially on the WEG3 indicator (absorption). The indicator has an outer loading value that is below 0.7 so it should be dropped. This means that millennial employees lacked the absorption behavior in this study. Reflected in today's millennials are easily stressed and bored and less focused on routine work as a result of the handphone they have always held. So just doing the job, a fraction of a minute the millennial generation will occasionally hold $a$ handphone and check the social media they have. Moreover, coupled with the level of welfare they get is not comparable, then work engagement will decrease.

\begin{tabular}{|c|c|c|c|c|c|}
\hline & $\begin{array}{c}\text { Original } \\
\text { Sample } \\
\text { (O) }\end{array}$ & $\begin{array}{c}\text { Sample } \\
\text { Mean } \\
\text { (M) }\end{array}$ & $\begin{array}{l}\text { Standard } \\
\text { Deviation } \\
\text { (STDEV) }\end{array}$ & $\begin{array}{l}\text { T Statistics } \\
\text { (|O/STDEV|) }\end{array}$ & $\begin{array}{c}\mathbf{P} \\
\text { Values }\end{array}$ \\
\hline WLB $->$ WEG $->$ KIN & 0,141 & 0,141 & 0,045 & 3,150 & 0,001 \\
\hline TKS -> WEG -> KIN & $-0,003$ & $-0,001$ & 0,027 & 0,101 & 0,460 \\
\hline
\end{tabular}

Table 7 above shows that the indirect relationship between Welfare Level variables to Employee Performance through Work Engagement is invalid and results in an evaluation of the rejected hypothesis. Because the T Satat value is $0.101<1.96$ and the P-Value is $0.460>0.05$. While the indirect relationship between Work-Life Balance to Employee Performance through Work Engagement produces valid value and the resulting evaluation of the hypothesis is accepted. Because all values T stat $>$ 1.96 and P-Value $<0.05$.

To assess how much effect mediation has on intervening variables this study can use baron and Kenny theory (1986) in (Ghozali, 2021). The effect of mediation of Work Engagement variables as mediation between Work-Life Balance variables against Employee Performance variables results in a full mediated evaluation. Because direct and indirect influences have equally significant results. While the effect of Work Engagement variable mediation as mediation between Welfare Level variables to Employee Performance variables resulted in an evaluation of no mediation effect. Because direct and indirect influences both result in insignificant evaluations.

The phenomenon in this study found that Work Engagement variables used as intervening variables that mediate between Welfare Level and Employee Performance variables did not produce a mediation effect. Because the Millennial Employees in this study lacked the behavior of Vigor, Dedication, and Absorption. On the contrary, employees in the millennial generation on the Work-Life balance variable feel full of balance in time management, engagement balance, balance in the 
fulfillment of expectations, and balance of satisfaction. This activity is carried out by showing vigor and dedication behavior, on daily activities in working towards improving the company's performance.

\section{E. CONCLUSION}

The Level of Well-being in this study cannot be mediated by Work Engagement which has measuring indicators such as Vigor, Dedication, and Absorption. But Work Engagement, which has measuring indicators such as Vigor and Dedication, can only mediate between Work-Life balance and measuring indicators such as balance in time management, engagement balance, balance in expectation fulfillment, and satisfaction balance. Absorption indicators in Work Engagement cannot be used to measure influence in this study. Because millennial employees are more prone to boredom in routine work and more often grasp handphone to check social media owned. So that interrupted by the work they do when they feel a long time, millennials can entertain themselves with social media and other entertainment in their gadgets. For this research to continue and continue, the author's advice is to add or change the appropriate exogenous indicators and still place work engagement variables as intervening variables. The goal is to know and confirm appropriate variables that can affect the performance of millennial employees through Work Engagement.

\section{REFERENCES}

1. Basikin. (2007). Vigor, Dedication and Absorption: Work engagement among secondary school English teachers in Indonesia. Yogyakarta: Universitas Negeri Yogyakarta

2. Darwin, M. (2020). The Effect of Communication Strategy in Marketing 4.0 Purchase Decision Through Brand Advocacy in Shopee E-Commerce. Http://Journal.Stiemb.Ac.Id/Index.Php/Mea/Article/View/482, 4(2), 375-396.

3. Darwin, M., \& Umam, K. (2020). Indirect Effect Analysis on Structural Equation Modeling (Comparative Study of Using Amos and SmartPLS Software). Nucleus, 50-57. https://doi.org/10.37010/nuc.v1i2.160

4. Deilotte Indonesia Perspective 2019 First Edition, September 2019.

5. Edukasi.kompas.com. (2019). 10 Negara Kemampuan Kompetitif Global Terbaik, Posisi Indonesia Naik.

6. https://edukasi.kompas.com/read/2019/02/06/10465231/10-negara-kemampuankompetitif-global-terbaik-posisi-indonesia-naik?page=all

7. Ghozali, I. (2021). Partial Least Square: Konsep, Teknik dan Aplikasi Menggunakan Program SmartPLS 3.2.9 (3rd ed.). Badan Penerbit Universitas Diponegoro.

8. Gichuhi \& Mbithuka. (2018). Influence of Work Engagement on Millennial Employees Retention among Insurance Industry in Kenya. International Journal of Innovative Research \& Development

9. Haryono, S. (2016). Metode SEM untuk penelitian manajeman dengan AMOS LISREL PLS (Vol. 53, Issue 9). https://doi.org/10.1017/CBO9781107415324.004

10. IDN Media, 2019. Indonesia Millenial Report 2019. IDN Research Institute. 
11. Johari, J., Tan, F. Y., \& Zulkarnain, Z. I. T. (2018). Autonomy, workload, work-life balance and job performance among teachers. International Journal of Educational Management.

12. Nurwahyuni. (2019). Pengaruh Beban Kerja Terhadap Kinerja Karyawan Melalui Work Life Balance (Studi Kasus PT. Telkom Indonesia Regional V). Jurnal Ilmu Manajemen, (1).

13. Nurwulandari, A., \& Darwin, M. (2020). Heywood Case Data Statistics: Using The Model Respesification Technique. Nucleus, 74-84. https://doi.org/10.37010/nuc.v1i2.17

14. Nindyati, A. D. (2017). Pemaknaan Loyalitas Karywan pada Generasi X dan Generasi Y, Studi pada karyawan di Indonesia. Journal of Psychological Science and Profession (JPSP)

15. Ningsih. (2013). Subjective Well Being Ditinjau Dari Faktor Demografi (Status Pernikahan, Jenis Kelamin, Pendapatan). Jurnal Online Psikologi

16. Nafiudin. (2015). Pengaruh Work Life Balance dan Kepuasan Kerja Terhadap Turnover Intention Karyawan Pada PT Bank Agroniaga Tbk Cabang Bandung. Jurnal Sains Manajemen.

17. Oktaviani, H. (2015). Pengaruh work life balance dan perceived organizational support terhadap turnover intention melalui organizational commitment sebagai variabel intervening pada PT. Berlian Jasa Terminal Indonesia.

18. Pratiknyo. (2020). "Covid-19 Memuluskan Era Revolusi Industri 4.0" April, 2020. Universitas Surabaya

19. Paramitadewi, K. F. (2017). Pengaruh Beban Kerja Dan Kompensasi Terhadap Kinerja Pegawai Sekretariat Pemerintah Daerah Kabupaten Tabanan. E-Jurnal Manajemen Unud

20. Rahman, U. U., Rehman, C. A., Imran, M. K., \& Aslam, U. (2017). Does team orientation matter? Linking work engagement and relational psychological contract with performance. Journal of Management Development

21. Rahmawati, A. (2016). Pengaruh Keseimbangan Kehidupan Kerja (Work Life Balance) Dan Kepuasan Kerja Terhadap Loyalitas Guru SMK Swasta di Kecamatan Cakung Jakarta Timur. Jurnal Manajemen Pendidikan

22. Schaar. A. K, A. Calero Valdez, Tatjana Hamann, M. Ziefle. (2019). Industry 4.0 and Its Future Staff. Matching Millennials Perceptions of A Perfect Job With The Requirements of Digitalization. COMA'19.

23. Sefudin, A., \& Darwin, M. (2020). Perbandingan Teori Disrupsi Pada Marketing di Era Industri 4.0 Menurut Hermawan Kartajaya dan Rhenald Kasali. In KOMITMEN: Jurnal Ilmiah Manajemen (Vol. 1, Issue 2).

24. Setkab.go.id. Peran Generasi Milenial Bagi NKRI, Maret 2019. https://setkab.go.id/peran-generasi-milenial-bagi-nkri-2/

25. Singh, S., \& Koradia, K. (2017). Psychological well-being and work-life balance of working women a correlation study. International Journal of Scientific $\mathcal{E}$ Engineering Research.

26. Thibaut, J., \& Kelley, H. (1959). The social psychology of groups. New York: Wiley. 
27. Utari, P. I., Yuniasanti, R., \& Fitriana, N. (2019). Hubungan Antara Perceived Organizational Support Dengan Workplace Well-Being pada Karyawan PT. X Yogyakarta. Universitas Mercu Buana Yogyakarta.

28. Vijayakumari, K., \& Vrinda, K. C. (2016). Work Engagemnet in Relation To Psychological Well-Being and Motivation at Work. Guru Journal of Behavioral and Social Sciences.

29. Wen, C. T. Y., Muthuveloo, R., \& Ping, T. A. (2018). Factors Influencing Job Satisfaction: A Perspective of Millennials in Malaysia Multinational (MNC) Companies. An International Journal.

30. Yongxing, G., Hongfei, D., Baoguo, X., \& Lei, M. (2017). Work engagement and job performance: the moderating role of perceived organizational support. Anales de Psicologíal Annals of Psychology, 33(3), 708-713. 